\title{
PARTICULARITIES OF THE FORENSIC SCIENCE INVESTIGATION OF TRANSNATIONAL SERIOUS CRIMES
}

\section{PARTICULARIDADES DE LA INVESTIGACIÓN EN CIENCIAS FORENSES DE DELITOS TRANSNACIONALES GRAVES}

Delia MAGHERESCU ${ }^{1}$

\begin{abstract}
The issue of serious crimes committed in a transnational or even supranational manner, as the specialists have stated before, involves more interest from the forensic science experts in their approaches in order to find a way of balance in analyzing and investigating the phenomena arose in the field of various criminality more spread currently. They have been taken into account by the forensic experts due to the fact that there are dilemmas they are confronted with. One of these leads with the idea of how serious crimes are investigated by means of forensic science's methods, technologies in the crimes trace of unauthorized technological transfer of nuclear or radioactive sources from the profile stations to the organized criminal groups' receivers. The current paper focuses on an atypical situation less discussed among the forensic experts facing serious states on achieving the forensic science examinations. It is about the technological transfer of nuclear or radioactive resources the organized criminal groups use in order to stock and sell it to the terrorist organizations, interested in manufacturing the mass destroying arms. The current paper approaches the scientific potential resources the forensic science provides on unconventional barriers of organized criminal groups in purpose to investigate from the forensic science's point of view the aspects of unauthorized technological transfer, collecting and stocking the nuclear and radioactive materials.
\end{abstract}

Resumen: La cuestión de los delitos graves cometidos de manera transnacional o incluso supranacional, como han señalado los especialistas anteriormente, involucra un mayor interés de los expertos en ciencias forenses en sus enfoques para encontrar una forma de equilibrio en el análisis e investigación de los fenómenos surgidos en El campo de la criminalidad más extendida actualmente. Los expertos forenses los han tenido en cuenta debido a que se enfrentan a dilemas. Uno de ellos conduce a la idea de cómo se investigan los delitos graves mediante los métodos de la ciencia forense, las tecnologías en los delitos rastrean la transferencia tecnológica no autorizada de fuentes nucleares o radiactivas desde las estaciones de perfil a los receptores de los grupos delictivos organizados. El documento actual se centra en una situación atípica menos discutida entre los expertos forenses que enfrentan estados serios para lograr los exámenes de ciencias forenses. Se trata de la transferencia tecnológica de recursos nucleares o radiactivos que los grupos delictivos organizados utilizan para almacenar y vender a las organizaciones terroristas, interesadas en fabricar armas de destrucción masiva. El presente documento aborda los recursos potenciales científicos que la ciencia forense proporciona sobre las barreras no convencionales de los grupos delictivos organizados con el fin de investigar desde el punto de vista de la ciencia forense los

\footnotetext{
${ }^{1}$ Doctor in Law, the degree awarded at the State University of Moldova, R. of Moldova, in 2005. Lawyer at the Gorj Bar Association, Tirgu Jiu, Romania. delia_magherescu@yahoo.com
} 
aspectos de la transferencia tecnológica no autorizada, la recolección y el almacenamiento de materiales nucleares y radiactivos.

Keywords: Forensic science investigation; Forensic science technology; Organized criminal groups; Radioactive material; Transnational criminality; Unauthorized technological transfer

Palabras clave: investigación en ciencias forenses; Tecnología de la ciencia forense; Grupos delictivos organizados; Material radioactivo; Criminalidad transnacional; Transferencia tecnológica no autorizada.

\section{Introduction}

Committing transnational serious organized crimes does not represent such a difficult activity of investigation for the judicial bodies, in particular for the forensic experts. Scientific techniques of the forensic criminalistics, as a progress science ${ }^{2}$, succeeded in covering almost all areas of these criminal typologies. Nevertheless, a real challenge for the judicial authorities is featured by discovering and investigating serious forms of criminality arisen at the supranational level. On this topic, it is remarkable that the phenomenon of criminality is also currently close to the progress and, for this point of view, both concept of criminality, on the one hand, and forensic science, on the other hand, appear in a continuous "competition". Thus, the organized criminal groups are permanently looking for developing their activity in such a way to achieve new valences on the vast field of criminality. At the same time, the judicial bodies are staying on emergency position in purpose to find new scientific techniques and methods of both preventing and combating the serious and very serious phenomena being interested in staying one step before the criminality.

In such an antagonistic architecture, the criminality investigation occurs a central place setting up in special around the concept of the international judicial cooperation ${ }^{3}$, which has had significant results in fighting the transnational criminal scourge, also seen as a concept of security ${ }^{4}$. However, the classical forms of transnational organized crime do not mean an obstacle in the forensic criminal

\footnotetext{
2 STANCU, E., Tratat de criminalistica, Bucharest: Actami Publishing House, 2001, p. 11.

3 VERMEULER, G. DE BONDT, W. RYCKMAN, C., Rethinking international cooperation in criminal matters in the EU, 2012, online available at:

https://books.google.ro/books?hl=en\&lr=\&id=uXZVTvDgQe8C\&oi=fnd\&pg=PA15\&dq=international+cooperation+in + criminal+matters\&ots=PX4lgIEnun\&sig=5ENTND5qfFBKv0iOkl9CIOmkUaI\&redir esc=y\#v=onepage\&q=internati onal\%20cooperation\%20in\%20criminal\%20matters\&f=false (accessed on 14 April 2019)

${ }^{4}$ CARRAPICO, H., Transnational organized crime as a security concept. In F. Allum \& S. Gilmour (Eds.), Routledge Handbook of Transnational Organized Crime, New York: Routledge, 2012, pp. 19-34.
} 
investigation being indifferently what kind of forms they are featured with, either of trafficking of any kind (drugs, weapons and human beings) or those of smuggling, counterfeiting a.s.o. ${ }^{5}$. However, the very serious forms of transnational criminality is still a challenge for the investigation bodies who are involved in finding practical solutions in purpose to combat or control these phenomena as much as possible ${ }^{6}$.

Taking into account all these aspects stated above, in order to reach the scope of solving legally the penal cases of transnational serious organized crimes ${ }^{7}$ based on scientific evidence there have been pointed out certain aims, as follows:

- identifying the main factors which unleash organized criminal groups' tools of committing serious transnational crimes;

- providing the methods used by the forensic experts in carrying out their activity of forensic investigation of transnational serious crimes;

- presenting forensic techniques used in this activity;

- identifying the gaps on the level of technologies existing at present;

- formulating certain proposal of improving the mechanism of investigation of the serious crimes' typologies.

The methodology of research of the serious crimes' typology is that based on the qualitative method, the research paper being a conceptual one.

\section{Conceptual Approach}

In researching the serious crimes, committed at the transnational level, both doctrine and jurisprudence have emphasized several points of view. In order to describe in detail the modality of

\footnotetext{
5 MAGHERESCU, D., New specific techniques of investigation for the economic offences. In A. Motatu \& I. N. Militaru (Eds.). Diversity and Interdisciplinarity in Business Law, Bucharest: Adjuris - International Academic Publisher, 2017, pp. 177-192, online available at: http://www.adjuris.ro/reviste/daib/Diversity\%20and\%20Interdisciplinarity\%20\%20\%20\%20\%20\%20\%20in\%20Busine ss\%20Law.pdf (accessed on 2 June 2019)

"STAMATIN, S., Fenomenul crimei organizate transfrontaliere. Analele Stiintifice ale Academiei "Stefan cel Mare" a MAI a Republicii Moldova, no. XI(2)/ 2011, pp. 80-87, online available at: https://ibn.idsi.md/sites/default/files/imag_file/16.Fenomenul\%20crimei\%20organizate\%20transfrontaliere.pdf (accessed on 2 June 2019)

7 ASHWORTH, A., Sentencing and Criminal Justice. Cambridge: Cambridge University Press, 2015, online available at:

https://books.google.ro/books?hl=en\&lr=\&id=kUhLCgAAQBAJ\&oi=fnd\&pg=PR13\&dq=scientific+evidence+the+pen al+cases+transnational+serious+organized+crimes\&ots=NXEbm4Sj9S\&sig=0o4ywQqIvym8YqeFf-OTvOfnSjs\&redir esc $=\mathrm{y} \# \mathrm{v}=$ onepage \&q\&f=false (accessed on 22 May 2019)
} 
forensic investigation of these forms of criminality a general framework of approaching this issue must be highlighted. In this regard, the following concept has been provided based on the idea that in cases of causing explosions in the nuclear stations or radioactive material deposits the forensic investigators must know the fact that on the other side of the world the organized criminal groups are developing mass destroying arms because of the nuclear or radioactive materials gathered from such controlled criminal explosions. In these circumstances, the criminal activities has became notoriously among forensic experts.

Since the beginning of the 20th century, the transnational organized crime investigators' natural tendency is that of knowing mechanism and techniques of capturing and transferring nuclear/ radioactive material on distances which involve continents. Once they stated the expression "on the other side of the world" they also refer to manufacturing the mass destroying arms by the organized criminal groups as a de facto expression.

In this context, there are two hypotheses which can be expressed.

(1) The organized criminal groups take themselves advantage directly of nuclear/ radioactive resources in order for them to obtain huge amount of money, or

(2) The organized criminal groups transfer such materials producing energy in order to obtain benefits on the "black" criminal market of the illegal resources of energy.

From this point of view, there is so-called "black market" of energy used unfortunately for criminal purposes. As a consequence, the transnational crimes provided above are very serious ones. This is because in fact it is not only about the illegal traffic of nuclear/ radioactive material, but more particularly on developing mass destroying arms which are commercialized finally to the terrorist groups $^{8}$.

The concept of the "international market of serious organized crime and terrorism" is not thus considered as a new one. It has been discussed multilaterally due to the atypical character this kind of criminality is featured with ${ }^{9}$.

Jurisprudential speaking, a real issue is arising at present more particularly to know if the judicial authorities in criminal matters both at the national and international levels have the appropriate legal

\footnotetext{
${ }^{8}$ SCHLEGEL, L., Who, Why, What, When, Against Whom? The Problem With Researching the Effectiveness of Terrorism. The Geopolitics, March 2019, online available at: https://thegeopolitics.com/who-why-what-when-against-whom-the-problem-with-researching-the-effectiveness-of-terro rism/ (accessed on 11 June 2019)

${ }^{9}$ LAFREE, G., DUGAN, L., MILlER, E., Putting Terrorism in Context. Lessons from the Global Terrorism Database. London: Routledge, 2014, pp. 83-201. https://doi.org/10.4324/9781315881720
} 
instruments for carrying out the forensic investigation of these forms of transnational serious crimes. It is appreciated that both science and progress do not characterize only the forensic science investigations and their areas of competence, the scientific methods and the means used, all in all the scientific technologies the forensic science provides the forensic experts with.

\section{The Background}

In spite of both the doctrine and jurisprudence references, the current paper is focused on a particular hypothesis regarding the unauthorized technological transfer of nuclear/ radioactive material by the organized criminal groups. In gathering them they use specific criminal means and technology that also belong to the terrorist groups. For this reason, in achieving the proposed aim of the current research, a concrete delimitation between the two criminal activities including not only the modus operandi, but the strategies as well as the concept used by themselves too is necessary. In order to better understand the phenomenon researched in the current paper as well as its mechanism, a list of conventional symbol table containing terms and expressions used subsequently has been settled.

\section{Table 1. Exemplification of Symbols Used in the Research Paper}

\begin{tabular}{|l|l|}
\hline Symbol & Signification \\
\hline S & Source of nuclear/ radioactive material deposit \\
\hline R & Receiver of nuclear/ radioactive material deposit \\
\hline UTT & Unauthorized technological transfer \\
\hline S/R & Aleatory locations \\
\hline UTP & Unauthorized technological process \\
\hline
\end{tabular}

A first-hand support of forensic investigation is given by the connection established between the Source and Receiver. The source means the explosion effects provoked criminally, while the receiver is the device set up by the organized criminal groups they use in purpose to collect the nuclear/ radioactive energy which is stoked in order to process and use it also in a criminal purpose. For the forensic expert there are three mechanisms of developing action. 
(i) One of these is the method of setting up the source consisting in the technical method of producing criminal provoked explosion.

(ii). The second mechanism refers to the technological method of transferring and collecting of the nuclear/ radioactive source.

(iii). Finally, the third mechanism is the receiver as a tool of the modus operandi finalization. Indeed, in such context, the forensic expert will be the most interested in investigating receiver of collecting and stocking the derived from the criminal provoked explosion.

At the same time, the technological process of transferring nuclear/ radioactive source to the receiver is of high interest in the matter. In the Figure 1. provided below it is highlighted hypothetically the trajectory of the process of criminal technological transfer having as object the nuclear/ radioactive material. Its itinerary has been chosen in an aleatory manner.

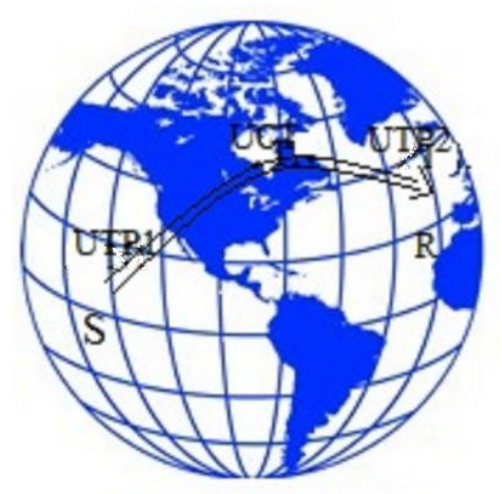

Fig. 1: Existence of the Unauthorized Criminal Technological Transfer Report of Nuclear/ Radioactive Material

Thus, it is obviously the particularity that defines this kind of criminality:

- committing it transnational;

- the organized criminal groups participation in such activities having leaders, strategies and members all over the world;

- the criminal modus operandi consisting in releasing certain controlled explosions in the nuclear stations/ radioactive material deposits. 
It should be stated the fact that relating to the transnational offenses the terrorist attacks are not taken into consideration, but only those committed by the organized criminal groups. Actually, the offenses committed by organized criminal groups can be connected to the terrorist ones but then during the second phase they manage of.

Regarding the differences between the organized criminal groups' activity and that carried out by the terrorist ones ${ }^{10}$, in this matter, several differences as well as connections has been highlighted between them as provided below in Table 2 .

Table 2: Disposing Similitudes and Differences Between the Organized Criminal Groups' Activity and the Terrorist One

\begin{tabular}{|c|c|}
\hline Organized criminal group & Terrorist group \\
\hline \multicolumn{2}{|c|}{ Differences } \\
\hline $\begin{array}{c}\text { Purpose targeted: seizing, } \\
\text { transferring, stocking, selling the } \\
\text { nuclear/ radioactive material }\end{array}$ & $\begin{array}{l}\text { Purpose targeted: selling nuclear/ } \\
\text { radioactive material }\end{array}$ \\
\hline $\begin{array}{l}\text { Collaboration with terrorist groups in } \\
\text { carrying out criminal activity }\end{array}$ & $\begin{array}{l}\text { Provoking some criminal activities of } \\
\text { gathering nuclear/ radioactive material } \\
\text { from the source }\end{array}$ \\
\hline Aiming at patrimonial purpose & No aiming at patrimonial purpose \\
\hline \multicolumn{2}{|c|}{ Similitude } \\
\hline \multicolumn{2}{|c|}{ Acting at transnational level } \\
\hline \multicolumn{2}{|c|}{ Provoking controlled explosions } \\
\hline The result of the crim & activity: killing civilians \\
\hline
\end{tabular}

Source: Own work

\section{Criminal Investigation Particularities}

${ }^{10}$ SCHLEGEL, L., idem, p. 1. 
The particularities of these kinds of serious crimes such as the transnational organized criminal ones release subsequently a special category of forensic investigation activity. The main elements of such special kind of investigation ${ }^{11}$ coexist with the classic ones carried out during the ordinary procedure. In other words, the new technical scientific means viewed as factor of modernity during the forensic investigation activity of the serious crimes belonging to the transnational organized crime ones cannot be separated from the traditional, classical elements. They must be integrated each other in the whole unit.

The explosions controlled by the organized criminal groups are featured by destroying partially or totally of the nuclear station or radioactive material deposit. This activity focuses on using deliberately methods and substances which release the explosion. In these cases, usually special explosive materials are used.

During the forensic investigative activity the issue of determining nature and source of explosive materials $^{12}$ used by the organized criminal groups is arisen. Basically, it consists in the following aspects.

a) Establishing the nature of explosion; regarding this issue the modality of releasing explosion must be determined by using new technological means the forensic science provides the investigators with. At the same time, the situation involving the issue of total or partial explosion, the degree of its force as well as the duration of explosion must be taken into account and clarified.

b) Establishing the circumstances the explosion was released in. At this stage of the investigation, it is very important for the forensic investigators the time in which the nuclear station was active or was out of work.

c) Establishing the space the explosion was released from, either at a distance, or closely.

d) Establishing the motivel scope of offence, they also being key elements for the forensic expert in carrying out the activity of investigation of the offence traces within the crime scene ${ }^{13}$.

e) Determining the executing offence of explosion modus operandi, in this case being excluded the variant of committing with guiltiness of this kind of criminal act.

\footnotetext{
11 NEWBURN, T., WILliAMSON, T., WRIGHT A., Handbook of criminal investigation, New York: Willan Publishing, 2007.

12 MAGHERESCU, D., idem, p. 182.

${ }^{13}$ DOUGlas, J. E., BURGESS, A. W., BURGESS, A. G., RESSLER, R. K., Crime Classification Manual. A Standard System for Investigating and Classifying Violent Crime, New Jersey: Wiley, 2013, online available at: https://books.google.ro/books?hl=en\&lr=\&id=j4CNiiDyOFQC\&oi=fnd\&pg=PT18\&dq=forensic+examination+in+orga

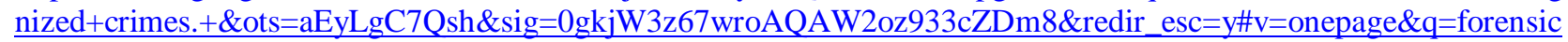
\%20examination\%20in\%20organized\%20crimes.\&f=false (accessed on 12 June 2019)
} 
The explosions controlled criminally are concentrated, released by deflagration which are based on explosive substances such as trinitrotoluene and nitroglycerine alongside with the action of electrical accessory mechanisms.

De facto, the explosion controlled criminally is the result of a complex of criminal acts such as preparing action plan achieved through obtaining means, produces, substances which contribute to achieving the result of criminal plan. Thus, it is obviously that from the modus operndi point of view the explosion controlled by the organized criminal groups mean just a phase of the entire criminal activity, which is released through the preparing acts, then it is followed by the proper explosion, unauthorized technological transfer, stocking the nuclear/ radioactive material within the receiver deposit and finally, its commercialization on the criminal "black market" to the terrorist groups.

The graphic modality of executing the transnational organized criminal link is showed below in the Figure 2.

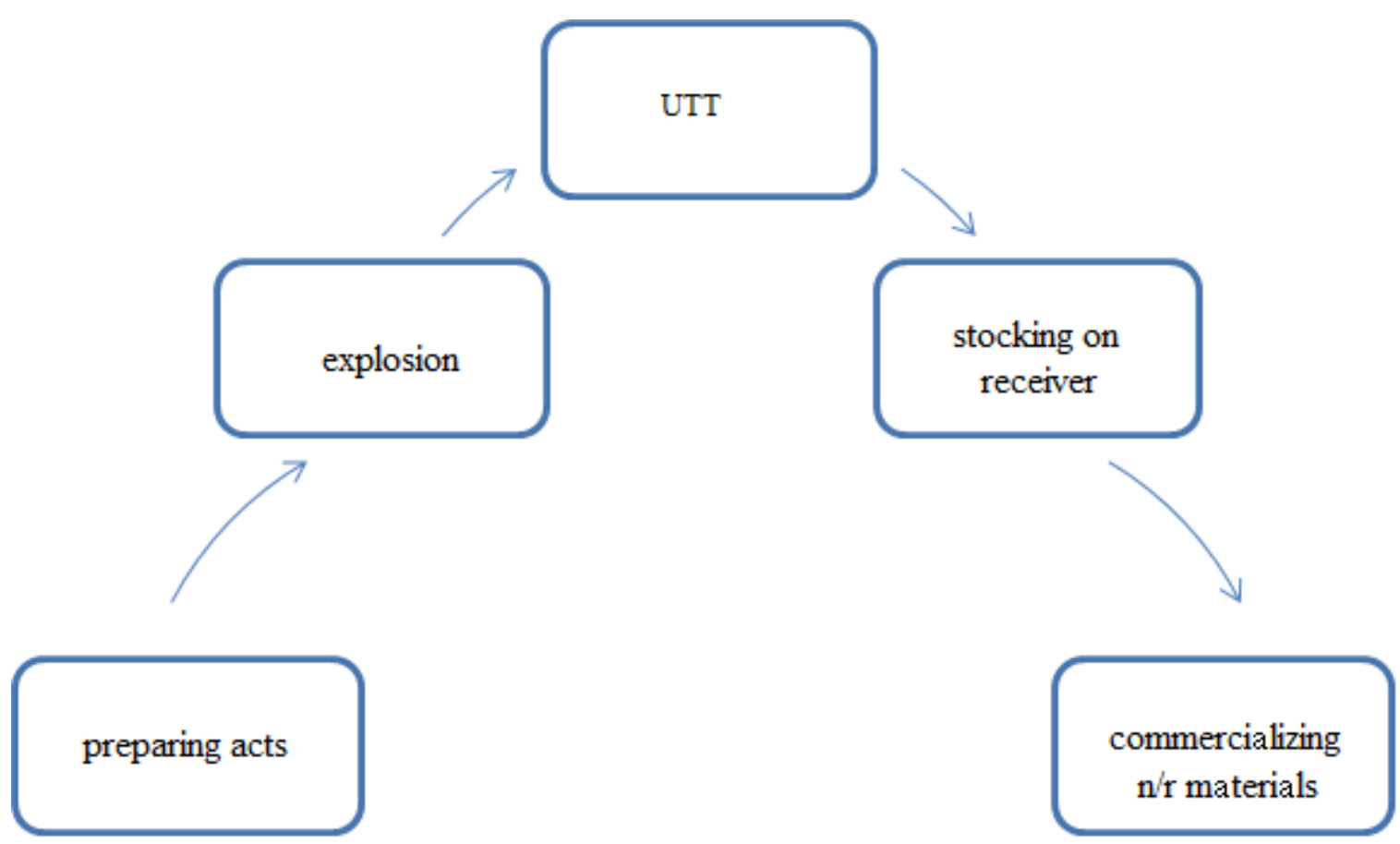

Fig. 2: Circuit of Organized Criminal Groups' Activity in Cases of Transnational Serious Crimes 
Equally, the explosion can be released accidentally. This kind of explosion is also profitable for organized criminal groups which are able in these circumstances to release their own technological mechanism of achieving the proposed goal. Otherwise, this is a real opportunity for the organized criminal groups to be involved in techniques of achieving the criminal result. This kind of explosion can be based on both objective causes linked to the technical or organizational deficiencies and subjective ones generated by the human errors in exercising the professional activity, such as negligence a.s.o.

f) Identifying the perpetrators ${ }^{14}$ in cases of technological transfer of nuclear/ radioactive material as well as those participants whose knowledge the terrorist groups use of. Although they do not belong to the organized criminal groups, they still contribute to the executing criminal activity. From this point of view, the activity of identifying criminals is a very difficult one due to the fact that they proceed to faraway locations, not only from the other countries but most of the time from the other continents.

In this context, the procedure consists in investigating the crime scene ${ }^{15}$ and determining the modus operandi of the organized criminal groups through involving certain homologous forensic investigative organizations from different countries. In this stage, the issue of investigating the way of unauthorized technological transfer as well as the receiver location is the main objective. In fact, this is the target of the activity of forensic investigation of transnational serious organized crimes. Once the receiver is localized, it is a matter of time until identifying the members of organized criminal groups.

The activity of identifying members of organized criminal groups is carried out in accordance with the methods and tactics provided by forensic sciences regarding the procedure of identifying people $^{16}$.

14 GUITTON, C., KORZAK, E., The Sophistication Criterion for Attribution: Identifying Perpetrators of Cyber-Attacks. The RUSI Journal, 2013, 158(4), pp. 62-68, online available at: https://www.tandfonline.com/doi/abs/10.1080/03071847.2013.826509 (accessed on 22 May 2019)

${ }^{15}$ DUTELLE, A. V., BECKER, R. F., Criminal Investigation, Fifth Ed., Jones and Bartlett Learning, Burlington, 2019 , pp. 67-93, online available at:

https://books.google.ro/books?hl=en\&lr=\&id=hVBLDwAAQBAJ\&oi=fnd\&pg=PP1\&dq=defense+in+forensic +crimina $\underline{1+\text { cases\&ots=NIzD7CmOPf\&sig=xJK6wI2tBAhgtlAHPpdPZMK2L8U\&redir esc=y\#v=onepage\&q=defense } \% 20 \text { in } \% 2}$ Oforensic\%20criminal\%20cases\&f=false (accessed on 29 June 2019)

${ }^{16}$ STANCU, E., idem, pp. 107-108. 
Depending on the way of releasing explosion the perpetrator, as a person qualified in the area of releasing and detonating explosions controlled criminally or the amateur persons in this kind of offenses, will be identified.

g) Identifying technical means and methods used in committing offenses. In executing the criminal activity the organized criminal groups adopt specific measures of criminal action in such a way to avoid discovering them by the judicial authority. This is a general feature of the criminal activity, thus the preparing actions ${ }^{17}$ and the proper ones are in these cases executed carefully through a well-organized action plan established in detail.

In carrying out the criminal action the organized criminal groups know very well de facto situation existing at nuclear stations/ deposits of radioactive materials whose "robbing" they are going to commit. The criminal attacks are not committed aleatory. Regarding the actions a detailed documentation is done most frequently via internal workers who agree to provide useful information to the organized criminal groups in exchange for a huge amount of money.

h) Investigating the crime scene. In this matter additional explanations are needed. It is about two different locations which mean "the place of committing offense". This means that there will be carried out two different investigations of the place of offence ${ }^{18}$. On the one hand, the first place of committing offence is that related to the nuclear station/ deposit of radioactive material, where the explosion was released, and on the other hand, the place where the receiver is situated or the one where the organized criminal groups stock the nuclear/ radioactive material transferred from source. Regarding the first aspect other supplementary explanations are not necessary due to the fact that they do not imply any difficulties during the forensic criminal activity of the crime scene. Otherwise, regarding the second location the procedure of investigation is more difficult due to the fact that they are unknown for the forensic investigators. This means that they imply a huge effort on discovering such locations situated faraway. The difficulties also arisen in missing witnesses who can testimony on the de facto situation ${ }^{19}$.

\footnotetext{
17 CHATZIIOANNOU, K., The criminalization of hacking tools as a reasonable measure of protection regarding attacks against information systems and computer data. In M. Bottis, E. Alexandropoulou, I. Iglezakis (Eds.), Values and Freedoms in Modern Information Law and Ethics - Proceedings of the 4th International Conference on Information Law and Ethics, Ethens: Nomiki Bibliothiki Group, 2012, pp. 123-133, online available at: file:///F:/articles_2012 07.pdf (accessed on 5 June 2019)

${ }^{18}$ FINDLAY, M., Juror comprehension and the hard case-Making forensic evidence simpler, International Journal of Law Crime and Justice, 2008, 36 (1), pp. 15-53. http://dx.doi.org/10.1016/j.ijsl.2007.07.001

${ }_{19}$ COHEN, D., Assessing the use of DNA expert evidence, by justice system participants, in Ontario criminal courts, University of Ontario Institute of Technology, August 2017, pp. 52, online available at: https://ir.library.dc-uoit.ca/bitstream/10155/828/1/Cohen_Dawn.pdf (accessed on 12 May 2019)
} 
Moreover, once they have been found it could be too late due to the fact that the organized criminal groups stock nuclear/ radioactive material during a short period of time, then it is trafficked illegally to the terrorist groups. For this reason, it is appreciated that organized criminal groups appear as intermediate persons in this context. Thus, if the forensic investigators discover the organized criminal groups' deposits after transferring nuclear/ radioactive material, then the forensic activity of investigation could be insignificant. It is considered that a perfect synchronization is necessary in order to achieve the purpose of the forensic activity of investigation regarding the place of committing serious crimes.

Related to the efficiency of the forensic activity of investigation, the most relevant characteristics are to be taken into consideration. They refer to the following aspects:

- urgent investigation, due to the fact that there is the possibility of destroying or missing the offence traces and evidence;

- systematizing organization of forensic investigation activity in cases of investigating the place of committing offenses;

- planning activity of investigating the place of committing offense;

- efficiency of forensic investigation activity for discovering and gathering evidence in purpose to solve the penal case.

Regarding the activity of investigating the place of committing offence in cases of explosions controlled criminally by the organized criminal groups to the nuclear stations/ deposits of radioactive material, it has been pointed out that the explosion is by definition a rapid chemical reaction released through fast escape of a large quantity of substance having both thermic and mechanic effect and result in destroying structures which are situated in close of their action area. As a rule, the results of investigating the place of committing offenses has demonstrated that the explosions are released by a cocktail containing several chemical substances.

i) Establishing conditions the offence was committed in. It is about determining the explosive material used, the circumstances regarding the blocking systems of security of the nuclear stations/ deposits of radioactive material. Thus, both the objective factors regarding the moment of committing offence, such as the attack during the night time, and subjective ones regarding the explosive substance used, the workers' negligence or even blocking the security systems are to be taken into account by the forensic investigators. 
Regarding the accidental explosions, they are committed by negligence as a result of accumulation of a big quantity of gas within the area of nuclear stations/ deposits of radioactive material. They are diffused, consisting in an mixture of oxygen and gas vapors. The flaw and threadbare installations or even the negligent manipulation by human can cause accidental explosions.

\section{Carrying Out the Forensic Examination}

The offenses of transnational organized crime, such as releasing explosions in a nuclear station/ radioactive deposit as well as capturing and stocking nuclear/ radioactive material are very serious crimes due to the fact that the perpetrators are looking for preparation of committing another offence consisting in trafficking in nuclear/ radioactive material on the international criminal market and in manufacturing mass destroying arms in order to by sold to the international terrorist groups. Finally, the arms gathered from these offenses are used in committing terrorist attacks ${ }^{20}$. The diagram of organizing and disposing organized criminal activity by the transnational criminal groups are provided below.

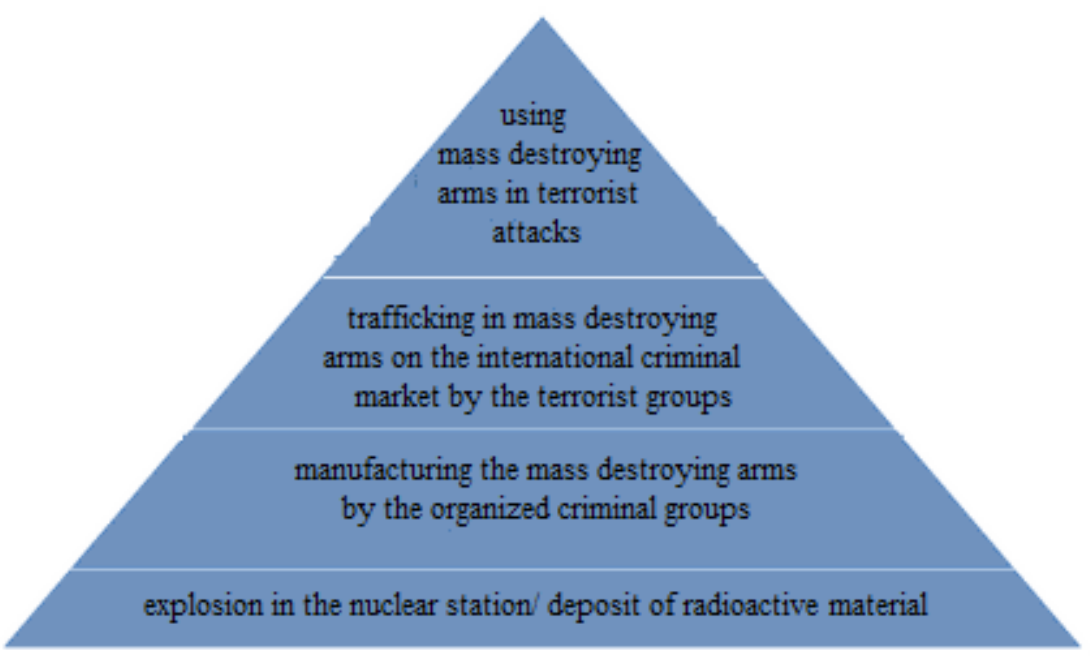

Fig. 3: Evolution of Organized Criminal Activity from Releasing Explosion in the Nuclear Station/ Deposit of Radioactive Material Till the Moment of Using Mass Destroying Arms

\footnotetext{
${ }^{20}$ AMBOS, K., Treatise on International Criminal Law. The Crimes and Sentencing, Oxford: Oxford University Press, 2014, online available at: https://books.google.ro/books?hl=en\&lr=\&id=i9tMAgAAQBAJ\&oi=fnd\&pg=PP1\&dq=nuclear+criminal+attacks\&ots =kSIfyrx0KA\&sig=WR-G3rtWFIjG3ULH11K6vMHiwQ\&redir_esc=y\#v=onepage \&q=nuclear\%20criminal\%20attac ks\&f=false (accessed on 6 June 2019)
} 
The information provided above states a complex of serious crimes in particular of transnational organized crimes ${ }^{21}$.

The main objective of the forensic investigation is that related to the following elements:

- identifying nuclear/ radioactive material embezzled from the nuclear stations/ deposits of radioactive material in order to recover it;

- identifying perpetrators in order to formulate accusation in accordance with their guilt.

This is the classical scenario disposed in cases of common offenses, but related to the serious crimes the situation is different due to the particularities the serious crimes present. More particular, the complex feature of these offenses is that characterizes such particularities.

The offence is complex and consists in the following criminal acts:

- producing explosion in the nuclear stations/ deposits of radioactive material;

- embezzling nuclear/ radioactive material;

- unauthorized technological transfer from source to receiver;

- stocking nuclear/ radioactive material;

- manufacturing mass destroying arms;

- trafficking/ selling mass destroying arms to the terrorist groups;

- using mass destroying arms in the terrorist attacks.

Disposing forensic examination is a procedural act common for those cases of investigating transnational organized crimes committed by explosion/ detonation. Carrying out such forensic examination has the main role of establishing both identifying perpetrator and criminal means used. In the field of forensic examinations that would be disposed by the judicial bodies the most frequent are:

- forensic examination of the explosion and arson traces;

- forensic examination of the traces discovered at the crime scene;

- forensic examination of the nuclear/ radioactive material from the nuclear stations/ deposits of radioactive material;

- forensic examination of the traces/ material discovered on the crime scene.

21 SAVONA, E., WILliAMS, P., The United Nations and Transnational Organized Crime. London: Routledge, 2012. https://doi.org/10.4324/9780203044315 
In spite of these kinds of forensic examination provided above, the forensic experts are not able to synthesize common examinations, such as those based on achieving the fingerprint evidence also being considered irrefutable evidence ${ }^{22}$.

In order to achieve the forensic examination in these cases the methods used by the forensic science of identifying the trafficked substances will be taken into account by the forensic experts. Due to their known chemical composition, the prohibited investigated substances have a huge value on the international black market ${ }^{23}$. The difficulty of identifying them intervenes in cases in which the judicial experts choose the most efficient analytical procedures that will highlight a particular identification for each substance.

One of the most important phase of the forensic examination is that of identifying the substance. The specific tests used by the forensic experts led usually to the best result in practice. They are the photometry in infrared spectrum and the mass photometry spectrum which determine substance through excluding the other ones. Moreover, the forensic experts also use other kinds of tests, such as microcrystlline and chromography.

The report of forensic examination is corroborated with the other means of evidence administered in the penal case. This is because the evidence do not have a pre-established judicial value, but the judicial bodies have the duty to administer the pertinent, conclusive and useful evidence during the investigation phase. They will then help in finding the truth and solving the penal case legally.

Thus, all these methods of forensic investigation will be achieved by joint operational teams established in the purpose of facilitating judicial activity of criminal investigation at the national level $^{24}$.

\section{Conclusions}

The offence of criminal controlled explosion in a nuclear station/ deposit of radioactive material is doubled by the trafficking in nuclear/ radioactive material on the criminal black market to the terrorist groups. For this reason, it must be stated that the crime of explosion is one of danger, while the crime of stocking the nuclear/ radioactive material and its trafficking is one of result. In the fist

\footnotetext{
${ }^{22}$ Committee on Identifying the Needs of the Forensic Sciences Community, National Research Council, Strengthening Forensic Science in the United States: A Path Forward, The National Academies Press, Washington, 2009, pp. 101-102, online available at: http://www.nap.edu/catalog/12589.html

${ }^{23}$ STANCU, E., idem, p. 706.

${ }^{24}$ MATASSA, M., NEWBURN, T., Social context of criminal investigation. In T, Newburn, T. Williamson, A. Wright (Eds.), Handbook of criminal investigation, New York: Willan Publishing, 2007, p. 51.
} 
situation, the offence is committed in purpose to prepare committing the other ones more serious in particular that of stocking nuclear/ radioactive material in order to manufactured mass destroying arms.

Generally speaking, the forensic examination in such cases is carried out based on the same methodology used in similar cases having as object the offenses produced through explosion followed by arson. In cases of the forensic examinations of explosion trances they establish the nature of explosion, the type of explosive material used, the mechanism of producing explosion. A difficult situation appears when the explosion is faraway controlled via the electronic devices linked to wireless sources or internet. In such cases, there is no the perpetrators' human traces on the crime scene and, for this reason, the forensic investigators are usually confronted with the impossibility of identifying them. This is a real inconvenient they are faced with.

Basically, the forensic science is a progress and technological development activity. Equally, it must be taken into account the fact that the organized criminal groups set up at the supranational level through managing networks having their own scheme and organizational strategy well-structured did not remain in a stand-by position. Otherwise, the real situation states that the huge amount of money gathered from this kind of criminal activity committed at the transnational level have created appropriate tools for developing organized criminal organizations.

The explosion controlled criminally represents a real source of profit for the organized criminal groups which initiate them. In this context, the aim of forensic examination of establishing cause of releasing explosion, the criminal modus operandi, the source used, the modality of device action (on the crime scene or at a distance, taking into account a very long distance too), which means for the forensic experts "on the other side of the world", namely on the other continent as well as the future risks are a real challenge for the forensic expert called to investigate the explosion traces.

At the same time, from a judicial point of view, the scientific motivated answers were found regarding the future effects of the valuating this source of energy by the organized criminal groups both on medium and long time.

For them, the explosions controlled criminally are important financial sources of criminal produce for the reasons already pointed out in the current paper.

Certain actions are proposed for a long time. They lead to:

- identifying and monitoring the organized criminal groups' networks all over the world;

- intensifying the international judicial cooperation in criminal matters; 
- increasing operational exchange of information between states ${ }^{25}$;

- acting directly on the organized criminal groups' networks through means based on transfer of experience and expertise.

In this matter, a great emphasis is insisted on streamlining borders control, but it is well-known that this kind of transnational organized criminality transcends the close area of some neighboring states, thus the regional area. The expression "on the other side of the world" is not used in a figurative meaning, but in a proper one. Considering all these aspects, the issue of border control appears as unseasonable. Moreover, it must be provided by the other categories of transnational offenses.

In conclusion, the paper evaluated a hypothesis specified in the current research results which was scientifically argued. It creates thus a theoretical basis regarding the fact that the forensic investigators invested in such a penal case must be familiarized with this typology of very serious crimes, complex and complicated ones which are committed in a transnational manner, although they do not imply the neighbouring states, but those situated faraway, on the other side of the world. The current paper contains elements of appropriate legislation in criminal matters the forensic investigators awaited a long time ago for. It is an endeavour so much awaited by the judicial investigation bodies of the European Union Member States which fight with the older mechanisms of accessing adequate evidence. At the moment, the most efficient method of gathering transnational evidence is given by the European Investigation Order which replaced the international rogatory commission.

The European Investigation Order supposes a tool of the international judicial cooperation ${ }^{2621}$ which knew some doctrinaire criticisms due to the procedural discords with the measures implemented. The main impact of such order on the judiciary is that it permits the judicial bodies of a state to dispose disclosing and keeping evidence including the digital ones in another state in order to use them during the investigations in criminal proceedings.

In the era of digital technology which occurs the entire world, a new position of both judicial and legislative authorities at the international level must imperatively intervene in order to adopt the

\footnotetext{
25 MEDEANU, T., Criminalitatea in actiune - omorul, terorismul si crima organizata. Bucharest: Lumina Lex Publishing House, 2006.

${ }^{26}$ GLESS, S., Transnational Cooperation in Criminal Matters and the Guarantee of a Fair Trial: Approaches to a General Principle. Utrecht Law Review, 2013, 9(4), pp. 90-108, file:///F:/244-553-1-PB.pdf
} 
adequate legislative solutions more efficient which must result in controlling and stopping the phenomenon discussed in the current paper.

Actually, the current legislation is more lightly and for this reason the organized criminal groups and terrorist ones became more advanced from the technological point of view, being spread up in several countries all over the world. In such a legislative framework, they succeed in avoiding both their identification and finally criminal liability.

Developing and improving continuously the digital instruments provided by the legislator and judicial bodies are considered sine qua non conditions of the judicial system evolution. As a consequence, at the moment, one of the most important measure which must be taken into account is one that refers to the transnational judicial cooperation in criminal matters which must be facilitated with the help of newer technology.

\section{Acknowledgement}

I would like to thank to the Ius et Scientia's Editorial Board and reviewers who agreed with my article and accepted it to be published in the next issue of the journal. It is the result of my own research work I was involved in during a period of several months, as a consequence there is no financial source provided for its publishing process.

\section{Conflict of interest}

There is no conflict of interest related to the paper published.

\section{References}

AMBOS, K., Treatise on International Criminal Law. The Crimes and Sentencing, Oxford:

Oxford University Press, 2014, online available at:

https://books.google.ro/books?hl=en\&lr=\&id=i9tMAgAAQBAJ\&oi=fnd\&pg=PP1\&dq=nuclear+cri

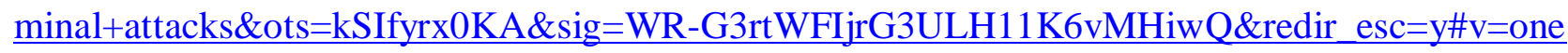
page \&q=nuclear\%20criminal\%20attacks \&f=false

ASHWORTH, A., Sentencing and Criminal Justice. Cambridge: Cambridge University Press, 2015. online available at: https://books.google.ro/books?hl=en\&lr=\&id=kUhLCgAAQBAJ\&oi=fnd\&pg=PR13\&dq=scientifi 
IUS ET SCIENTIA (ISSN 244-8478) 2019, Vol. 5, nº 2, pp. 55-75 PARTICULARITIES OF THE FORENSIC SCIENCE INVESTIGATION OF TRANSNATIONAL SERIOUS CRIMES.

$\underline{\mathrm{c}+\text { evidence+the+penal+cases+transnational+serious+organized+crimes\&ots=NXEbm4Sj9S\&sig=0 }}$ o4ywQqIvym8YqeFf-OTvOfnSjs\&redir_esc=y\#v=onepage\&q\&f=false

CARRAPICO, H., Transnational organized crime as a security concept. In F. Allum \& S. Gilmour (Eds.), Routledge Handbook of Transnational Organized Crime, New York: Routledge, 2012.

CHATZIIOANNOU, K., The criminalization of hacking tools as a reasonable measure of protection regarding attacks against information systems and computer data. In M. Bottis, E. Alexandropoulou, I. Iglezakis (Eds.), Values and Freedoms in Modern Information Law and Ethics - Proceedings of the 4th International Conference on Information Law and Ethics, Ethens: Nomiki Bibliothiki Group, 2012, online available at: file:///F:/articles_2012_07.pdf

COHEN, D., Assessing the use of DNA expert evidence, by justice system participants, in Ontario criminal courts, University of Ontario Institute of Technology, August 2017, pp. 52, online available at: https://ir.library.dc-uoit.ca/bitstream/10155/828/1/Cohen Dawn.pdf

COMMITTEE on Identifying the Needs of the Forensic Sciences Community, National Research Council, Strengthening Forensic Science in the United States: A Path Forward, The National Academies Press, Washington, 2009, online available at: http://www.nap.edu/catalog/12589.html DOUGLAS, J. E., BURGESS, A. W., BURGESS, A. G., RESSLER, R. K., Crime Classification Manual. A Standard System for Investigating and Classifying Violent Crime. New Jersey: Wiley, 2013 , online available at: https://books.google.ro/books?hl=en\&lr=\&id=j4CNiiDyOFQC\&oi=fnd\&pg=PT18\&dq=forensic+e xamination+in+organized+crimes.+\&ots=aEyLgC7Qsh\&sig=0gkjW3z67wroAQAW2oz933cZDm

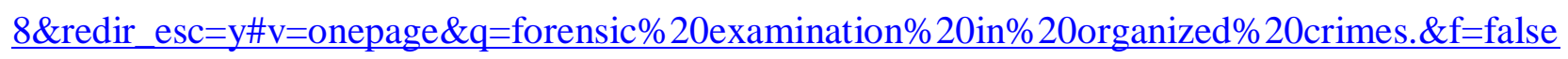
DUTELLE, A. V., BECKER, R. F., Criminal Investigation, Fifth Ed., Jones and Bartlett Learning, Burlington, 2019, online available at: https://books.google.ro/books?hl=en\&lr=\&id=hVBLDwAAQBAJ\&oi=fnd\&pg=PP1\&dq=defense+ $\underline{\text { in }+ \text { forensic }+ \text { criminal }+ \text { cases \&ots=NIzD7CmOPf\&sig }=x J K 6 w I 2 t B A h g t l A H P p d P Z M K 2 L 8 U \& r e d i r ~}$ esc $=\mathrm{y} \# \mathrm{v}=$ onepage $\& \mathrm{q}=$ defense $\% 20 \mathrm{in} \% 20$ forensic $\% 20$ criminal $\% 20$ cases $\& \mathrm{f}=$ false

FINDLAY, M., Juror comprehension and the hard case-Making forensic evidence simpler, International Journal of Law Crime and Justice, 2008, 36 (1), pp. 15-53. http://dx.doi.org/10.1016/j.ijs1.2007.07.001 
IUS ET SCIENTIA (ISSN 244-8478) 2019, Vol. 5, nº 2, pp. 55-75 PARTICULARITIES OF THE FORENSIC SCIENCE INVESTIGATION OF TRANSNATIONAL SERIOUS CRIMES.

Delia Magherescu, State University of Moldova, delia magherescu@yahoo.com

Recibido: 17/09/2019. Aceptado: 10/10/2019 DOI: http://doi.org/10.12795/IESTSCIENTIA.2019.i02.04

GLESS, S., Transnational Cooperation in Criminal Matters and the Guarantee of a Fair Trial: Approaches to a General Principle. Utrecht Law Review, 2013, 9(4), online available at: file:///F:/244-553-1-PB.pdf

GUITTON, C., KORZAK, E., The Sophistication Criterion for Attribution: Identifying Perpetrators of Cyber-Attacks. The RUSI Journal, 2013, 158(4), online available at:

https://www.tandfonline.com/doi/abs/10.1080/03071847.2013.826509

LAFREE, G., DUGAN, L., MILLER, E., Putting Terrorism in Context. Lessons from the Global Terrorism Database. London: Routledge, 2014, https://doi.org/10.4324/9781315881720

MAGHERESCU, D., New specific techniques of investigation for the economic offences. In A.

Motatu \& I. N. Militaru (Eds.). Diversity and Interdisciplinarity in Business Law, Bucharest:

Adjuris - International Academic Publisher, 2017, online available at:

http://www.adjuris.ro/reviste/daib/Diversity\%20and\%20Interdisciplinarity\%20\%20\%20\%20\%20\% 20\%20in\%20Business\%20Law.pdf

MATASSA, M., NEWBURN, T., Social context of criminal investigation. In T, Newburn, T. Williamson, A. Wright (Eds.), Handbook of criminal investigation, New York: Willan Publishing, 2007.

MEDEANU, T., Criminalitatea in actiune - omorul, terorismul si crima organizata, Bucharest: Lumina Lex Publishing House, 2006.

NEWBURN, T., WILLIAMSON, T., WRIGHT A., Handbook of criminal investigation, New York: Willan Publishing, 2007.

SAVONA, E., WILLIAMS, P., The United Nations and Transnational Organized Crime. London: Routledge, (2012). https://doi.org/10.4324/9780203044315

SCHLEGEL, L., Who, Why, What, When, Against Whom? The Problem With Researching the Effectiveness of Terrorism. The Geopolitics, March 2019, online available at: https://thegeopolitics.com/who-why-what-when-against-whom-the-problem-with-researching-the-ef fectiveness-of-terrorism/

STAMATIN, S., Fenomenul crimei organizate transfrontaliere. Analele Stiintifice ale Academiei "Stefan cel Mare" a MAI a Republicii Moldova, XI(2), 2011, online available at: https://ibn.idsi.md/sites/default/files/imag_file/16.Fenomenul\%20crimei\%20organizate\%20transfro ntaliere.pdf

STANCU, E., Tratat de criminalistica, Bucharest: Actami Publishing House, 2001. 
IUS ET SCIENTIA (ISSN 244-8478) 2019, Vol. 5, nº 2, pp. 55-75 PARTICULARITIES OF THE FORENSIC SCIENCE INVESTIGATION OF TRANSNATIONAL SERIOUS CRIMES.

Delia Magherescu, State University of Moldova, delia magherescu@yahoo.com

Recibido: 17/09/2019. Aceptado: 10/10/2019 DOI: http://doi.org/10.12795/IESTSCIENTIA.2019.i02.04

VERMEULER, G., DE BONDT, W., RYCKMAN, C., Rethinking international cooperation in criminal matters in the EU, 2012, online available at:

https://books.google.ro/books?hl=en\&lr=\&id=uXZVTvDgQe8C\&oi=fnd\&pg=PA15\&dq=internati onal+cooperation+in+criminal+matters\&ots=PX4lgIEnun\&sig=5ENTND5qfFBKv0iOk19CIOmkU aI\&redir_esc=y\#v=onepage $\& \mathrm{q}=$ international $\% 20$ cooperation $\% 20 \mathrm{in} \% 20 \mathrm{criminal} \% 20$ matters $\& \mathrm{f}=\mathrm{fal}$ $\underline{\text { se }}$ 